\title{
The Role of Business Strategy in Accomplishing Organization Mission in Nigerian Manufacturing Companies
}

\author{
Dr. David T. Isiavwe \\ Department of Accounting, Igbinedion University, Okada, \\ Dr. Mercy E.I. Ogbari \\ College of Business and Social Sciences, Covenant University Ota \\ Dr. Olaleke O. Ogunnaike \\ College of Business and Social Sciences, Covenant University Ota \\ Professor Dayo Ade-Turton \\ Department of Business Administration Elizade University
}

\begin{abstract}
The imperativeness of strategic alignment in attaining organizational objectives have become critical in this contemporary business age. The study examined the role of Business Strategy on Mission Accomplishment of Manufacturing companies with a major focus on mission statements of two multi-national companies in Nigeria. Probability and non probability sampling techniques were adopted. In the first stage, the two multinational companies were purposively selected among the list of registered manufacturing companies while in the second stage, a simple random sampling procedure was employed to draw participants from the organizations. A total sample of 384 participants was planned by the sampling procedure, however, only 291 participants were successfully interviewed. From the analysis, it was asserted that the employment of business strategy enhances organizational mission irrespective of the type, ownership, management and size of the organization. In addition, there is need for a thorough environmental scanning in order to select the appropriate business strategy to be adopted in accomplishing the specific aspect of the organization`s mission.
\end{abstract}

Keywords: Business Strategy, Organization`s Mission, Manufacturing Companies, Nigeria

\section{Conceptual Framework}

\subsection{Background to Study}

Nigeria 's quest for national development is expressed through the desire for rapid industrialization and technical progress. This has led to the establishment of industries of different sizes, functions, and capacities over time. Many of these industries are participants within the various sectors of the economy. They consist of different types such as the multi-national companies (MNCs), transnational companies (TNCs), and indigenous companies (INCs) as well as the Small and Medium Scale Enterprises (SMEs). However, Nigerian business environment remains stiff and turbulent as a result of competition and rivalry among these participants. The nature of competition among them and the corresponding strategic postures of these companies are the overall determinants of the market share and the revenue accruable to each of these companies (Bidunni, 2009; Grant, 2013).

For every company that wants to compete favourably in the market or at least survive in its business operations, strategic management practices must be religiously embraced and employed. The strategic management tasks involve definitions of vision and mission of the organization, setting of goals and objectives, crafting of strategies, implementing and executing the strategy crafted and finally monitoring, evaluating and taking corrective actions when necessary ( Drucker, 1974; Greengarten, Yau, Gitlow \& Scandura, 1996 ; Campbell, Shrives \& Bohmbach, 2001; Toftoy \& Chatterjee, 2004; Ade-Turton, 2011; David, 2013).

An organization's vision reflects management aspirations for the future by providing a panoramic view of where a company is going (Pearce \& David, 1987; Desmidt \& Prinzie, 2007; Shahhoseini, Toroghi, Abadi \& Panahi, 2013). It points an organization in a particular direction and charts a strategic path for it to follow. Statements of vision tend to be quite broad and can be described as a goal that represents an inspiring and emotionally driven destination. (Dess, Lumpkin \& Taylor, 2005). Mission, on the other hand, is the fundamental purpose of every organization. It deals with an organization's present scope-"who we are and what we do" (Drucker, 1974; David, 2009; Griffin, 2012; Maxwell, David \& Manilall, 2014). The organization's mission reflects the organization's values, beliefs and guidelines for its business. It is a vital communication tool to stakeholders -employees, customers, shareholders, suppliers, government and society. (Hitt, Black \& Porter, 2012; Darwin, Carl \& Kathleen, 2012). 
On the other hand, no matter how laudable the mission statement might sound coupled with versatile objectives to be achieved, the success of both "mission" and "vision" is contingent upon the drivers of strategies in terms of their competencies and understanding of the mission. Strategy is a comprehensive plan for achieving chosen objectives (Griffin, 2008). It specifies how the organization will be operated and run and the entrepreneurial, competitive and functional approaches and actions that will be taken to put the organization into the desired position (Oyedijo, 2004; Ogbari, Oke, Ajagbe \& Isiavwe, 2015). Today, businesses are faced with complex goals and strategies, coupled with different management and diverse employees from different background. In most cases, business strategies determine the success or failure of any business. The effective use of strategies helps to identify a path to achieving organizational mission and goals. It also helps identify and overcome barriers and obstacles in the way of successful implementation of organizational mission. However, efficiency is only possible if the strategies are aligned with the organization`s mission (Wang, Chen \& Chen, 2012).

In spite of the potency of strategy, the commitment of the top managers in mobilizing workers and other resources towards the execution and implementation of the crafted strategy is paramount in determining the competitiveness of a company. Strategy implementation and execution is an action-oriented, "make-it-happen" process involving people management, developing competencies and capabilities, budgeting, policy-making, motivating, culture-building and leadership. There are a number of companies with good strategies but unfortunately they failed to institute structures, policies and necessary drives for the implementation of such strategies (Chaneta, 2011; Dess, 2012; Bhandari, 2013).

\section{Business Strategies}

Porter (1998) propounded that cost leadership strategy emphasizes efficiency and if a firm can achieve and sustain overall cost leadership, it will be an above-average performer in its industry, provided it can command prices at or near the industry average. He claimed that by producing high volumes of standardized products, the firm hopes to take advantage of economies of scale and experience curve effects. However, low cost leadership is attached to a disadvantage which is less customer loyalty (Porter, 1985, Thompson \& Stickland, 2003, Brassington \& Pettitt, 2006; Schermerhorn, 2013). Relatively low prices will result in creating a negative attitude towards the quality of the product in the mindset of the customers (Miller, 1992). Customers" impression regarding such products will enhance the tendency to shift towards a product which might be higher in price but projects an image of quality. Considering analytical in-depth view regarding the low cost strategy, it reflects capability to generate a competitive advantage but development and maintenance of a low cost base becomes a vital, decisive task. It is in view of the above identified issues that the study examined how the adoption of overall cost leadership strategy helps in the accomplishment of product/service quality, process improvement and employee satisfaction as specified in the organization`s mission.

Porter (1980, 1998 and 2008) discussed differentiation strategy to involve creating a product that is perceived as unique, and that the unique features or benefits should provide superior value for the customer if this strategy is to be successful. In support of his views, Ibidunni (2009) observed that customers see the product as unrivaled and unequaled, the price elasticity of demand tends to be reduced and customers tend to be more brand loyal, hence this can provide considerable insulation from competition. To maintain this strategy, Ibidunni (2009) elaborates that the firm should have: strong research and development skills, strong product engineering skills, strong creativity skills, good cooperation with distribution channels, strong marketing skills, incentives based largely on subjective measures, be able to communicate the importance of the differentiating product characteristics, stress continuous improvement and innovation, and attract highly skilled, creative people. He however stressed that there is a disadvantage arising from the need to incur additional costs associated with the differentiating product features and this could require a premium pricing strategy. To this end, the study therefore determined how the adoption of differentiation strategy facilitates the accomplishment of process improvement, product/ service quality and employee satisfaction as specified in the organization`s mission (Ogbari, 2015).

Interestingly, companies throughout the world are seeking competitive advantage over one another by leading through innovation and innovative processes. Porter claimed that focus strategy is when the firm concentrates on a select few target markets, and by focusing efforts on one or two narrow market segments or specialized markets, the needs of the target markets can be met better. The firm that adopts this strategy typically looks to gain a competitive advantage through effectiveness rather than efficiency, as he interchangeably called it niche strategy, or market segmentation strategy. It is pertinent to note that the newly industrialized countries of Malaysia, South Korea, Hong Kong, Singapore, Brazil and Indonesia have injected various innovative techniques beyond new products (Baden - Fuller, \& Stopford 1994; Rodrigues, 2002; Aaker, 2005; Bankole \& Otokiti, 2007). The major concern is how effectively can focus as a strategy influence the accomplishment of quality customer service and community development as specified in the organizations' mission. 


\section{Research Methodology}

The central focus of the study is to examine the role of business strategy in mission accomplishment of organisations. The population of the study comprises management employees of two manufacturing companies in Lagos and environs. A sample size of 384 participants was determined using the Minimum Returned Sampling size determination formula by Bartlett, Kotrilik and Higgins (2001) since we are not categorically sure of the exact population size of the companies under study. Both purposive and random sampling techniques were adopted in the ratio of 50:49 between the two companies denoted as Company A\&B. Data were collected through the use of survey instrument. The survey dealt with the demographics of respondents and variables germane to both business strategy and mission. A total of 384 questionnaires were distributed to management employees of the organisations and only 291 were found useful which were eventually evaluated for the research (Creswell, 2012).

In determining the extent of mission accomplishment by business strategy, a 5point Likert scale ranging from strongly agree to strongly disagree with values 1-5 was developed with the aid of previous instruments from the work on strategy by Veetil, 2009 and Bordean et al, 2011. Univariate and multivariate analysis was adopted with the aid of SPSS software version 21 to analyze the data.

\subsection{Statistical Analyses and Findings}

Scales used in the study were separated by their dimensions and every dimension's reliability was tested by calculating the Cronbach Alpha value.

Table 1. Reliability of the Survey by its Dimensions

\begin{tabular}{|l|c|c|l|c|c|}
\hline Variables & $\begin{array}{c}\text { Number of } \\
\text { Questions }\end{array}$ & $\begin{array}{c}\text { Cronbach } \\
\text { Alpha }\end{array}$ & Variables & $\begin{array}{c}\text { Number of } \\
\text { Questions }\end{array}$ & $\begin{array}{c}\text { Cronbach } \\
\text { Alpha }\end{array}$ \\
\hline Low-cost strategy & 8 & 0,851 & Quality products & 2 & 0,784 \\
\hline Differentiation Strategy & 9 & 0,856 & Employee satisfaction & 2 & 0,727 \\
\hline Focus strategy & 5 & 0,780 & Community development & 2 & 0,657 \\
\hline & & & Process improvement & 2 & 0,831 \\
\hline & & & Productivity & 4 & 0.784 \\
\hline
\end{tabular}

Source: Researchers' Compilation (2015)

As indicated above in table 1, Cronbach Alpha coefficients ( ) of the scales used are reasonably reliable.

Information related to the demographic variables of the study are in the following tables.

Table 2. Socio-Demographic Characteristics of Respondents

\begin{tabular}{|c|c|c|c|c|c|c|c|}
\hline $\begin{array}{l}\text { Demographic } \\
\text { Values } \\
\end{array}$ & $\begin{array}{c}\text { Sub- } \\
\text { characteristics }\end{array}$ & $\mathbf{N}$ & $\%$ & Demographic Values & $\begin{array}{l}\text { Sub- } \\
\text { characteristics }\end{array}$ & $\mathbf{N}$ & $\%$ \\
\hline \multirow[t]{3}{*}{ Gender } & Male & 150 & 51.5 & \multirow[t]{3}{*}{ Management Cadre } & Lower Level & 111 & 38.1 \\
\hline & \multirow[b]{2}{*}{ Female } & \multirow[b]{2}{*}{141} & \multirow[b]{2}{*}{48.5} & & Middle Level & 103 & 35.4 \\
\hline & & & & & Top Level & 77 & 26.5 \\
\hline \multirow[t]{5}{*}{ Age } & Younger than 25 & 3 & 1.0 & \multirow[t]{5}{*}{ Working Experience } & Less than 5years & 217 & 74.6 \\
\hline & $25-35$ & 199 & 68.4 & & 5 years -9 years & 33 & 11.3 \\
\hline & $36-40$ & 44 & 15.1 & & 10 years \& Above & 41 & 18,6 \\
\hline & $41-50$ & 40 & 13.7 & & & & \\
\hline & Older than 50 & 5 & 1.8 & & & & \\
\hline \multirow[t]{2}{*}{ Marital Status } & Married & 230 & 79.0 & \multirow[t]{5}{*}{ Department } & Production & 168 & 57.7 \\
\hline & Single & 61 & 21.0 & & \begin{tabular}{|l|} 
Service \\
\end{tabular} & 69 & 23.7 \\
\hline \multirow[t]{5}{*}{$\begin{array}{l}\text { Educational } \\
\text { Level }\end{array}$} & $\begin{array}{c}\text { Primary } \\
\text { education }\end{array}$ & 7 & 2.4 & & Others & 54 & 18.6 \\
\hline & SSCE & 83 & 28.5 & & & & \\
\hline & OND/NCE & 25 & 8.6 & & & & \\
\hline & UNIVERSITY & 157 & 54.0 & & & & \\
\hline & OTHERS & 19 & 6.5 & & & & \\
\hline
\end{tabular}

Source: Researchers' Compilation (2015) 
The analysis above on table 2 . shows that the total percentage of the male respondent is 51.5 percent while females are 48.5 percent. Among the group, 21 percent were singles as at the time of the survey while 79 percent were married (Table 2). Also, the age distribution of total respondents who participated in the study ranges between ages 15 to 65 years. Smaller proportion of total respondents were in the lowest and highest age groups (20-25 and 50 years and above). About one percent belonged to the lowest age group while 1.8 percent were 50 years or more. The bulk of the population belonged to age group 25-35 years representing about 68.4 percent. The proportion of total respondents in age group 36-40 years was 15.1 percent. Group 41-50 years has only 13.7 percent. Overall, the age distribution presents a normal distribution curve, rising from the lowest, reaching a peak at age 30-34 years and maintaining a steady decline to the last age group.

In terms of the working experience, one out of every five respondents (of the total sampled population) have spent over 5 years with the companies selected and more than two-thirds of them have spent between one year and 4 years working with the company selected. Since young staff (in terms of working years) were excluded, the observation here was not surprising. The nature of the Nigerian economy coupled with frequent intra-and inter migration of young population and the desire for greener pasture always culminate in high turnover of staff in developing countries. Hence, the lower proportion of staff that have stayed with their companies above 4 years. The statistics on education status revealed that larger proportion of employees/staff of the companies sampled have attained up to tertiary education as at the time of the survey. All respondents are literates and majority (97.6\%) have had at least secondary education. Only 2.4 percent of the respondents had below secondary education. However, the proportion of respondents that had tertiary education included those with 25 individuals (about 8.6\%) who had Ordinary National Diploma (OND) and National Certificate of Education (NCE) and 54.0 percent who have attained University education.

Respondents' categories or levels resemble a downward slope curve from left to right. This indicates that it is bottom loaded and thins out at the higher level. This is expected of every company where larger numbers of employees are at the lower cadre and small proportion at the managerial or higher levels. The results show that 38.1, 35.4 and 26.5 percent of respondents were in the lower, middle and top managerial levels respectively. The distribution also cuts across various sections. While almost one-third (57.7 percent) were in the production/ manufacturing section, 23.7 percent work in the service section and 18.6 percent in other departments.

\subsection{Regression Analysis}

Regression analysis was carried out to determine the relationship between the independent and dependent variables below.

Table 3: Regression effects of overall cost leadership strategy on the accomplishment of product / service quality, and employee satisfaction as specified in the organization's mission.

\begin{tabular}{|c|c|c|c|c|c|c|c|c|c|c|}
\hline \multirow{3}{*}{$\begin{array}{l}\text { Overall cost } \\
\text { leadership } \\
\text { strategy }\end{array}$} & \multicolumn{5}{|c|}{ product /service quality } & \multicolumn{5}{|c|}{ employee satisfaction } \\
\hline & \multicolumn{2}{|c|}{$\begin{array}{l}\text { Unstd. } \\
\text { Coefficient }\end{array}$} & \multicolumn{2}{|l|}{$\begin{array}{l}\text { Std. } \\
\text { coeff. }\end{array}$} & & \multicolumn{2}{|c|}{$\begin{array}{l}\text { Unstd } \\
\text { coefficient }\end{array}$} & \multirow{2}{*}{$\begin{array}{l}\text { Std. } \\
\text { coeff. }\end{array}$} & \multirow[b]{2}{*}{$\mathrm{T}$} & \multirow[b]{2}{*}{ Sig. } \\
\hline & $\mathrm{B}$ & $\begin{array}{l}\text { Std } \\
\text { Error }\end{array}$ & $\mathrm{B}$ & $\mathrm{T}$ & Sig. & B & $\begin{array}{l}\text { Std. } \\
\text { Error }\end{array}$ & & & \\
\hline Constants & 1.865 & 0.050 & & $37.201 *$ & .000 & 1.938 & .045 & & $42.743 *$ & .000 \\
\hline $\begin{array}{l}\text { Overall cost } \\
\text { leadership }\end{array}$ & -.128 & .016 & -.432 & -8.137 & .000 & -.171 & .014 & -.578 & $-12.042 *$ & .000 \\
\hline $\mathrm{R}$ & .432 & .452 & & & & .578 & & & & \\
\hline $\mathrm{R}^{2}$ & .186 & & & & & .334 & & & & \\
\hline Adj. $R^{2}$ & \multicolumn{5}{|l|}{.184} & \multicolumn{5}{|l|}{.332} \\
\hline $\mathrm{F}$ & \multicolumn{5}{|l|}{66.204} & \multicolumn{5}{|c|}{145.003} \\
\hline Overall Sig. & \multicolumn{5}{|l|}{.000} & \multicolumn{5}{|l|}{.000} \\
\hline
\end{tabular}

$(* \mathrm{p}<0.01) * * \mathrm{p}<0.05) * * * \mathrm{p}<0.1)$

Source: Researchers' Compilation (2015)

\section{Hypothesis One}

$\mathrm{H}_{\mathrm{o}}$ : Cost leadership strategy has no impact in the accomplishment of product / service quality and employee satisfaction as specified in the organization's mission.

$\mathrm{H}_{\mathrm{a}}$ : Cost leadership strategy helps in accomplishment of product service quality, and employee satisfaction as specified in the organization's mission.

Table 3 summarizes the relationship between overall cost leadership strategy on the accomplishment of product / service quality and employee satisfaction as specified in the organization's mission. Overall cost leadership 
strategy significantly affects product / service quality of the organizations as well as the satisfaction of employees at 0.01 and 0.05 levels of significance respectively. This reveals that overall cost leadership influences product / service quality $(\mathrm{B}=-.128, \mathrm{p} \leq 0.005)$ and employee satisfaction $(\mathrm{B}=-0.171, \mathrm{p} \leq 0.005)$. Thus we accept the alternate hypothesis and reject the null hypothesis and conclude that cost leadership strategy helps in accomplishment of product service quality, and employee satisfaction as specified in the organization's mission.

\section{Hypothesis Two}

$\mathrm{H}_{\mathrm{o}}$ : Differentiation strategy does not facilitate the accomplishment of process improvement and employee satisfaction as specified in the organization's mission.

$\mathrm{H}_{\mathrm{a}}$ : Differentiation strategy facilitates the accomplishment of process improvement and employee satisfaction as specified in the organization`s mission.

Table4: Regression effects of Differentiation strategy on the accomplishment of process improvement and employee satisfaction as spelled out in the organization's mission and mission statement.

\begin{tabular}{|c|c|c|c|c|c|c|c|c|c|c|}
\hline & \multicolumn{5}{|c|}{ Process Improvement } & \multicolumn{5}{|c|}{ employee satisfaction } \\
\hline & \multicolumn{2}{|c|}{$\begin{array}{l}\text { Unstd. } \\
\text { Coefficient }\end{array}$} & \multirow{2}{*}{$\begin{array}{l}\begin{array}{l}\text { Std. } \\
\text { coeff. }\end{array} \\
\text { B }\end{array}$} & \multirow[b]{2}{*}{$\mathrm{T}$} & \multirow[b]{2}{*}{ Sig. } & \multicolumn{2}{|c|}{$\begin{array}{l}\text { Unstd } \\
\text { coefficient }\end{array}$} & \multirow{2}{*}{$\begin{array}{l}\begin{array}{l}\text { Std. } \\
\text { coeff. }\end{array} \\
\text { B }\end{array}$} & \multirow[b]{2}{*}{$\mathrm{T}$} & \multirow[b]{2}{*}{ Sig. } \\
\hline & $\mathrm{B}$ & Std Error & & & & $\mathrm{B}$ & $\begin{array}{l}\text { Std. } \\
\text { Error }\end{array}$ & & & \\
\hline Constants & 1.510 & 0.54 & & $27.764 *$ & .000 & 1.936 & .044 & & $43.704^{*}$ & .000 \\
\hline $\begin{array}{l}\text { Differentiation } \\
\text { strategy }\end{array}$ & -.022 & .017 & -.077 & -1.309 & .192 & -.167 & .014 & -.588 & - $12.352 *$ & .000 \\
\hline $\mathrm{R}$ & .077 & .452 & & & & .588 & & & & \\
\hline $\mathrm{R}^{2}$ & .006 & & & & & .346 & & & & \\
\hline Adj. $\mathrm{R}^{2}$ & \multicolumn{5}{|l|}{.002} & \multicolumn{5}{|l|}{.343} \\
\hline $\mathrm{F}$ & \multicolumn{5}{|c|}{1.712 .204} & \multicolumn{5}{|c|}{152.569} \\
\hline Overall Sig. & \multicolumn{5}{|l|}{.192} & \multicolumn{5}{|l|}{.000} \\
\hline
\end{tabular}

$(* \mathrm{p}<0.01) * * \mathrm{p}<0.05) * * * \mathrm{p}<0.1)$

Source: Researchers' Compilation (2015)

The coefficient table above shows the simple model that expresses the extent to which the adoption of differentiation strategy enhances the accomplishment of organization's mission in terms of process improvement, and employee satisfaction as specified in the organization's mission. Differentiation strategy does not significantly affect process improvement of the organizations but has significant influence on employees' satisfaction at 0.01 and 0.05 levels of significance respectively. This indicates that differentiation does not have significant influence on process improvement $(B=0.022, p \geq 0.05)$. However, differentiation strategy has significant influence on employee satisfaction $(\mathrm{B}=-0.167, \mathrm{p} \leq 0.05)$. Thus, in the case of process improvement we accept the null hypothesis and reject the alternate hypothesis and conclude that differentiation strategy does not facilitate process improvement as spelled out in the mission statement. On the other hand we reject the null hypothesis and accept the alternate hypothesis and conclude that differentiation strategy facilitates the accomplishment of mission as regards employee satisfaction as spelled out in the organization mission.

\section{Hypothesis Three}

$\mathrm{H}_{\mathrm{o}}$ focus strategy has no significant effect on the accomplishment of quality customer services and community development as specified in the organizations' mission

$\mathrm{H}_{\mathrm{a}}$ : focus strategy has significant effect on the accomplishment of quality customer services and community development as specified in the organizations' mission 
Table 5: Regression effects of Focus strategy on the accomplishment of quality customer services and community development as specified in the organizations' mission.

\begin{tabular}{|c|c|c|c|c|c|c|c|c|c|c|}
\hline & \multicolumn{5}{|c|}{ quality customer services } & \multicolumn{5}{|c|}{ community development } \\
\hline & \multicolumn{2}{|c|}{$\begin{array}{l}\text { Unstd. } \\
\text { Coefficient }\end{array}$} & \multirow{2}{*}{$\begin{array}{l}\text { Std. } \\
\text { coeff. } \\
\text { B }\end{array}$} & \multirow[b]{2}{*}{$\mathrm{T}$} & \multirow[b]{2}{*}{ Sig. } & \multicolumn{2}{|c|}{ Unstd coefficient } & \multirow{2}{*}{$\begin{array}{l}\text { Std. } \\
\text { coeff. } \\
\text { B }\end{array}$} & \multirow[b]{2}{*}{$\mathrm{T}$} & \multirow[b]{2}{*}{ Sig. } \\
\hline & $\mathrm{B}$ & $\begin{array}{l}\text { Std } \\
\text { Error }\end{array}$ & & & & $\mathrm{B}$ & $\begin{array}{l}\text { Std. } \\
\text { Error }\end{array}$ & & & \\
\hline Constants & 1.206 & 0.55 & & $21.948 *$ & .000 & 1.514 & .066 & & $22.952 *$ & .000 \\
\hline $\begin{array}{l}\text { Focus } \\
\text { strategy }\end{array}$ & .005 & .015 & -.077 & .021 & .723 & -.005 & .018 & -.016 & $-268^{*}$ & .789 \\
\hline $\mathrm{R}$ & .021 & .452 & & & & .016 & & & & \\
\hline $\mathrm{R}^{2}$ & .000 & & & & & .000 & & & & \\
\hline Adj. $\mathrm{R}^{2}$ & \multicolumn{5}{|l|}{-.003} & \multicolumn{5}{|l|}{-.003} \\
\hline $\mathrm{F}$ & \multicolumn{5}{|l|}{1.126} & \multicolumn{5}{|l|}{.072} \\
\hline Overall Sig. & \multicolumn{5}{|l|}{.723} & \multicolumn{5}{|l|}{.789} \\
\hline
\end{tabular}

\section{Source: Researchers' Compilation (2015)}

The coefficient table indicates the simple model summary of the regression equation that predicted the effect of focus strategy on the accomplishment of quality customer services and community development as specified in the organizations' mission. From the results, focus strategy has no significant effect on the accomplishment of quality customer services and community development as specified in the organizations' mission at 0.01 and 0.05 levels of significance respectively. This indicates that focus strategy does not make significant contribution towards accomplishment of quality customer services $(B=0.005, p>0.005)$ and community development $(B=$ $0.005, \mathrm{p}>0.005)$. Thus we accept null hypothesis and reject the alternate hypothesis and conclude that focus strategy has no significant effect on the accomplishment of quality customer services and community development as specified in the organizations' mission.

\section{Conclusion}

Every organisation pursues her mission statement through different strategies. However, the understanding of these strategies by the employees varies from one company to another. The alignment to company's strategies in achieving the mission and goals of the company by the employees is achieved through meeting the customers' needs, creation of value, admirable brands, customers' satisfaction and provision of basic needs. However, based on the findings of this study, it can be concluded that overall cost leadership strategy is useful for the accomplishment of both product/service quality and employee satisfaction as may be specified in the organizations' mission. The study also concludes that adoption of differentiation strategy is efficient for the accomplishment of process improvement. Understanding by workers in the pursuit of the organization's mission is key hence the need to carry them along. This can also be done by appraising company's performance regularly as well as offering effective marketing services coupled with consistent production of quality products. Notwithstanding, it is vital to know that achievement of organisation mission is contingent upon workers' belief in all ramifications. Workers are the pivot upon which the business rotates, hence the recommendation that workers' welfare should be among top priorities of any organisation. This could enhance their commitment and thereby raise productivity. Customers are also crucial as the existence of any company is dependent upon the availability of customers for her products or services. Thus, manufacturing to the specification and the need of customers and timely delivery (unhindered logistics) are critical determinants of achievement of organisation mission and these must be pursued vigorously.

\section{References}

Aaker, D.A. (2005). Developing business strategies. 6th Ed. New York, NY: John Wiley and Sons.

Ade-Turton, D. (2011). Management awareness and strategies for the contemporary African manager of organizations. Journal of Business \& Economics Research (JBER), 1(1).

Bankole, O., Jide, A. (2007). A synopsis of the ICT 4D sector in Nigeria incorporating activities of the Government, Private Sector and Non-Governmental Organizations.

Bhandari, R. (2013). Strategic management: A concept framework. Mc Graw Hill Education (India) Private Limited Green Park Extension New Delhi.

Bordean, O. N., A.I. Borza, \& Segura, D.G. (2011). A comparative approach of the generic strategies within the hotel industry: Romania vs USA. Management \& Marketing Challenges for Knowledge Society, 6(6), 501514. 
Campbell, D. Shrives P., \& Bohmbach, H, (2001). "Voluntary disclosure of mission statements in corporate annual reports: Signaling what and to whom?" Business and Society Review, 106(1), 65-87.

Chaneta, I. (2011). Strategic management process. Journal of Comprehensive Research, 5(1), 17- 25.

Creswell, J.W. (2012). "Educational research planning, conducting and evaluating quantitative and qualitative research" Pearson Publishers, $4^{\text {th }}$ Ed Australia: 239.

Darwin, L., Carl, J., \& Kathleen, M. (2013). 2012. Mission statements: A ten country global analysis. Academy of Strategic Management Journal, 12(1), 13.

David, R.F. (2009). Strategic management: Concepts and cases $10^{\text {th }}$ Ed. Barmer Pearson Education Inc. New Jersey.

David, R.F. (2013). Strategic management: concepts and cases: A competitive advantage approach, 14th Ed. Prentice Hall Professional Business.

Desmidt, S. \& A.A. Prinzie, (2007). The impact of mission statements: An empirical analysis from a sense making perspective.

Dess, G.G., Lumpkin, G.T. \& Taylor, M L. (2005). Strategic management. (2Ed). New York: McGraw-Hill Irwin.

Dess, G. (2012). Strategic management: Text and cases. New York. McGraw Hill Irwin.

Drucker, P. (1974). Management: tasks, responsibilities, and practices. New York, NY: Harper \& Roe.

Fuller C. \& Stopford J. M. (1994). Rejuvenating the mature business: The competitive challenge. Harvard Business School Press: Boston, MA.

Grant, R.M. (2013). Contemporary strategy analysis: Text and cases. Chi Chester, Wiley.

Greengarten-Jackson, J., Yau, S.C., Gitlow, H. \& Scandura, T.A., (1996). Mission statements in service and industrial corporations. International Journal of Quality Science, 1(1), pp.48-61.

Griffin, R.W. (2008). Fundamentals of management: Texas A \& M University.

Griffin, R.W. (2012). Fundamentals of Management: South-Western Cengage Learning, Mason.

Hitt, M.A., Black, J.S. \& Porter, L.W. (2012). Management (Third Edition). Upper Saddle River, NJ: Pearson Prentice Hall.

Ibidunni, O.S, (2009). Impact of competitive marketing on performance of multinational and Indigenous food and beverage manufacturing companies in Nigeria. A Ph.D thesis submitted to the Department of Business Studies, College of Business and Social Sciences Covenant University, Ota.

Maxwell, S., David, P., \& Manilall, D. (2014). Strategic planning and its relationship with business performance among small and medium enterprises in South Africa. International and Economics Research Journal, 13(3), 659-666

Miller, D. (1992). The generic strategy trap. Journal of business Strategy, 13(1), 37-41.

Ogbari, M. E., Oke, A. O., Ajagbe, A. M., \& Isiavwe, D. T. (2015). Evaluation of the correlation between mission statement and company performances in the banking industry. IIARD-International Institute of Academic Research and Development, 1(3), 1-14.

Ogbari, M. E. (2015). The effect of business strategy and ownership structure on mission accomplishment of manufacturing firms in Nigeria (Doctoral dissertation, Covenant University, Ota, Ogun State).

Otokiti, S. O. (2007) International business: How to get started in the international business environment, Dubai Printing Press, Dubai, United Arab Emirates.

Oyedejo, A. (2004). Strategic management: An introductory text. Strategic International Press Ltd. Ikeja, Lagos.

Pearce, J.A \& David, F. (1987). "Corporate mission statement: the bottom line". Academy of Management Executive, 1(2), 109-116.

Porter, M. E. (1980). Competitive strategy: Techniques for analyzing industries and competitors, New York: The Free Press.

Porter, M. E. (1985). Competitive advantage. Creating and sustaining superior performance, New York: The Free Press.

Porter, M. E. (1998). The Competitive advantage of nations. With a new introduction by the author, Macmillan Press Ltd.

Porter, M. E. (2008). The five competitive forces that shape strategy. Harvard Business Review. January, 86(1), $1-18$.

Rodrigues, S. (2002). Business strategy and organizational performance: An analysis of the Portuguese mould industry: A PhD thesis submitted to the University of Wolver Hampton.

Schermerhorn, J.R. (2013). Introduction to management (12th ed.). John Wiley \& Sons, Ltd, New Jersey

Shahhoseini, M.A, Toroghi, H.K, Abadi, Y. A. \& Panahi, A.B (2013). Identify the key elements for developing an organization's mission statement case study: North Khorasan University of Medical Sciences. Interdisciplinary Journal of Contemporary Research in Business. 5(1), 246-252.

Thompson, A. A., Gamble, J. E. \& Strickland, A. J. (2004) Strategy: Winning in the workplace. Boston: McGraw-Hill, Irwin. 
Toftoy, C. N. \& Chatterjee, J, (2004). "Mission statements and the small business". Business Strategy Review, $15,44-45$.

Veetil, N.M. (2009). "Strategy formulation and implementation in manufacturing organizations: The impact on performance", $\mathrm{PhD}$ thesis submitted to the Middlesex University Business School London, United Kingdom.

Wang, C., Chen, K. \& Chen, S. (2012). Total quality management, market orientation and hotel performance: The moderating effects of external environmental factors. International Journal of Hospitality Management, 31(1), 119-129. 